\title{
How Sustained Service-Learning Experiences Inform Career Pathways
}

\author{
Tania D. Mitchell \\ University of Minnesota
}

\author{
Colleen Rost-Banik \\ University of Minnesota
}

\begin{abstract}
Developing values, interests, and skills for future careers, an important part of career development, is an outcome alumni perceive from participation in service-learning. Using in-depth interviews, this qualitative study of 33 alumni from three service-learning programs suggests rich connections between sustained service-learning experiences (i.e., course-based community engagement programs lasting two or more consecutive terms) and career decisions. More specifically, alumni perceive their engagement in service-learning as facilitating exploration of career possibilities connected to public service and social responsibility.
\end{abstract}

Understanding how young adults develop their career paths affects the services and opportunities that postsecondary institutions offer for students. Rayman (1993) emphasized that college students' knowledge and understanding of their values, interests, skills, and motivations is central to career development. Grouping these characteristics under "self-knowledge" and adding the awareness of the working world and the ability to process and apply knowledge and skills, Rayman created a career-development paradigm fundamental to career counseling (Pipkins, Rooney, \& Jaunarajs, 2014). Complementing this paradigm, Krieshok, Black, and McKay (2009) credit experiential learning as optimal for career decision-making. Experiences help shape students' self-knowledge, and research shows that community settings are influential in developing students' values, interests, and skills (Moely \& Ilustre, 2014). A key way college students gain hands-on experiences in communities is through service-learning (Jacoby, 2009).

Distinct from volunteering, service-learning is an approach to teaching where students participate in service "that meets identified community needs and reflect on the service . . . to gain further understanding of course content, a broader appreciation of the discipline, and an enhanced sense of civic responsibility" (Bringle \& Hatcher, 1996, p. 222). Service-learning studies reveal statistically significant yields on outcomes including academic achievement, social skills, and attitudes toward self, school, and learning (Celio, Durlak, \& Dymnicki, 2011). Early writings on servicelearning predicted that students' experiences with service would affect their career choices (Franta, 1994; Kolenko, Porter, Wheatley, \& Colby, 1996). Simons and Cleary (2006) found that $82 \%$ of survey respondents felt that service-learning experiences affected their career development. In addition, Billig (2000) and Vogelgesang and Astin (2000) reported that students with servicelearning experiences were more likely to choose a service career upon graduation.

The experiences service-learners attain working in community settings can be both inspirational to the student and compelling to a prospective employer. Service-learning offers the role rehearsal career-development specialists see as important to preparing students for future work (Savickas, 1999; Savickas et al., 2009; Simons \& Cleary, 2006). Warchal and Ruiz (2004) suggest that service-learning "may offer students the opportunity to experience success in career settings and make informed choices about employment options" (p. 91).

While Vogelgesang and Astin (2000) found that $41.3 \%$ of college students who participated in service-learning intended to pursue a publicservice career, relatively little attention has been paid to the experiences of service-learning alumni to examine whether these intentions manifest in their actual career trajectory. The present study is guided by the following research questions: Do sustained service-learning experiences inform alumni career decisions toward public service? If so, what connections, experiences, and processes from the service-learning program do alumni perceive facilitated their career pathways?

\section{Literature Review}

\section{Skill Development and Self-Efficacy}

A key aspect of students' career development is the "self-knowledge" that allows them to make 
career decisions aligned with their interests, skills, values, and motivations (Rayman, 1993). Lent, Brown, and Hackett (2000) concur, suggesting that opportunities for skill development as a careerrelevant learning experience may provide a "direct influence" on career choice (p. 38). The better students recognize their values, interests, and skills, the better poised they are to make career decisions that match those traits. Research on skill development illustrates this link. Studying STEM (science, technology, engineering, and mathematics) career choice, Odera, Lamm, Odera, Duryea, and Davis (2015) found that offering college students the opportunity to experience science-based research through a summer internship developed skills that enhanced their feelings of competency and reinforced students' career choices in science-based fields. In another study, doctoral students who had internships with an associated course not only developed specific career-related skills but also displayed increased confidence in career exploration and decision-making (Schnoes et al., 2018). The time the course dedicated to career exploration and planning provided students with the space to talk with peers as well as be exposed to and consider the advantages and disadvantages of various career paths.

Supporting the link between career interests and self-efficacy, social cognitive career theory (SCCT) recognizes that people connect their career interests to skills in which they believe they are competent (Bandura, 1986; Lent, Brown, \& Hackett, 1994). This combination of career interests and selfefficacy then influences career choices and performance outcomes (Lent et al., 1994). For instance, a person who sees herself as competent in woodworking might develop a career interest in carpentry. In short, SCCT suggests that people develop interests and choose careers based on what they think they are good at. Bonitz, Larson, and Armstrong (2010) expanded SCCT to indicate the reverse. That is, the greater the interest one has in a position, the greater one's confidence in one's ability to do the job. This dynamic also influences career decisions. Using the previous example, a person drawn to a carpentry career might have more confidence in - and interest in developing - her woodworking skills. Recognizing that self-efficacy shapes career interests and career interests influence self-efficacy, SCCT offers a theoretical framework for understanding how students' involvement in a variety of learning experiences allows them to explore and deepen their interests, skills, and values, which has a recursive relationship in shaping career interests.

What we know about service-learning is that it shapes students' interests, values, skills, and self- efficacy (Meaney, Housman, Cavazos, \& Wilcox, 2012; Moely \& Ilustre, 2014). This self-efficacy, argues Hackett (1995), is "absolutely vital" to cultivating the strong sense of agency required for career choice and development (p. 253). Combining service-learning research with insights from SCCT and studies that link skill development to career choice, we can speculate that service-learning may inform students' career interests and decisions.

\section{Civic Commitments of Service-Learning Alumni}

Research on alumni of service-learning experiences is limited, and most studies are correlational due to the temporal, logistical, and financial challenges of implementing longitudinal and experimental designs with alumni. Given these realities, most of the research on this topic emphasizes questions of civic commitment and political engagement, focusing on how the service-learning experience continues to shape how alumni see themselves as civic actors (Denson, Vogelgesang, \& Saenz, 2005; Jones \& Abes, 2004; Vogelgesang \& Astin, 2000; Youniss \& Yates, 1997). According to these studies, alumni were politically engaged, involved in their communities, and committed to "socially responsible work" (Jones \& Abes, 2004, p. 156). The research shows that service-learning experiences can be a "clear landmark" (Youniss \& Yates, 1997 , p. 128) for alumni in the development of their identity and in their developing commitment to civic participation (Jones \& Abes, 2004; Kahne \& Sporte, 2008).

Missing from these studies, however, is information on the specific careers alumni pursue. Fenzel and Peyrot (2005) offer more information, reporting that $46 \%$ of respondents between one and six years post-graduation held jobs in the "service field." Alumni who completed 40 hours of community service during their college career and took a service-learning course, compared with those who only completed 40 hours of service, were more likely to report a service career. Fenzel and Peyrot's research suggests that the more time college students spend in community engagement experiences, the more likely they are to pursue public service careers post-graduation.

Warchal and Ruiz (2004) also found that "service-learning experiences are a significant factor in alumni postgraduate employment" (p. 101). Focusing on the connection between alumni perceptions of the quality of their community experience (e.g., very good or poor) and how that affected decisions to accept employment offers from public service jobs, they found that $32 \%$ of those with service-learning experience received employ- 
Table 1

Participants and Their Careers

\begin{tabular}{lcl}
\hline Participant by Institution & Graduation Year & \multicolumn{1}{c}{ Career } \\
\hline Foresight 1 & 2006 & Assistant Attorney General \\
Foresight 2 & 1999 & Early Childhood Educator \\
Foresight 3 & 1998 & School Social Worker \\
Foresight 4 & 2000 & High School Administrator \\
Foresight 5 & 2004 & Labor Organizer \\
Foresight 6 & 2005 & Political Strategist \\
Foresight 7 & 2000 & Therapist \\
Foresight 8 & 2005 & City Communications Director \\
Foresight 9 & 2006 & Social Worker \\
Foresight 10 & 1997 & Statewide Transportation Manager \\
Foresight 11 & 2002 & Family Nurse Practitioner \\
Manor 1 & 1995 & Corporate Executive \\
Manor 2 & 2004 & Philanthropic Foundation Director \\
Manor 3 & 2005 & Physician \\
Manor 4 & 2008 & PhD Graduate Student \\
& & Grad Student/Housing \\
Manor 5 & 2007 & Organizer \\
& & JD Graduate Student \\
Manor 6 & 2006 & Death Penalty Rights Organizer \\
Manor 7 & 1999 & Professor \\
Manor 8 & 1997 & Professor \\
Manor 9 & 2003 & Technology Company Executive \\
Manor 10 & 1995 & Management Consulting \\
Manor 11 & 1997 & Software Engineer \\
Pioneer 1 & 2008 & Community Organizer \\
Pioneer 2 & 2002 & Teacher \\
Pioneer 3 & 2008 & Food Security Organizer \\
Pioneer 4 & 2003 & MBA Graduate Student/Housing Organizer \\
Pioneer 5 & 2001 & Physician \\
Pioneer 6 & 2008 & Labor Organizer \\
Pioneer 7 & 2006 & Non-profit Program Manager \\
Pioneer 8 & 2002 & Adult Educator \\
Pioneer 9 & 2003 & Teacher \\
Pioneer 10 & 2010 & Delivery Service Operator \\
Pioneer 11 & 2007 & Teacher \\
\hline
\end{tabular}

ment offers from their service placements and that " $62.5 \%$ of them accepted the offer to work at that placement" (p. 97).

These positive correlations between servicelearning and public service careers indicate engagement in service is a valuable intervention for career decisions. Scholars have noted that further research on career decisions of service-learning alumni is an important direction for future research (Jones \& Abes, 2004; Vogelgesang \& Astin, 2000). This project aims to contribute to this much-needed conversation.

\section{Method}

This study focused on the alumni of three sustained service-learning programs at three postsecondary institutions. The programs differed in their institutional home, but all had deep connections to the campus public service office. The programs also differed in length: the one at Manor University, a private research university, lasted one year (three courses); the one at Pioneer University, a large public university, lasted two years (four courses); and the one at Foresight College, a small, Catholic College, lasted four years (11 courses). All of the programs had a shared mission to build civic agency among their students. Students self-selected into the programs, deciding to enroll in the various experiences and commit to the classes required to complete the program. While there were differences in institution type and program length, this was not a comparative study among institutions; rather, the study focused on the ways intentional, sustained service-learning programs informed career pathways for alumni. 


\section{Participants}

Working with each campus to compile a list of all former participants, a database of almost 400 alumni across the three service-learning programs was built (see Table 1). We employed a purposeful sampling technique to ensure race and gender generally mirrored the alumni pool; we divided alumni into groups by race and gender, assigned numbers to each individual, and used a random number generator to identify participants. Eleven alumni from each program ( $n=33 ; 72 \%$ female; $82 \%$ White), who graduated between 1995 and $2010(m d n=9$ years post-graduation), were interviewed. Of those interviewed, $60 \%$ worked in the public sector, $15 \%$ were pursuing graduate work, and $22 \%$ worked in the private sector. Researchers did not have prior knowledge of the alumni's careers, so they did not factor it into the sampling procedure.

\section{Protocol}

The interview protocol was guided by extant literature on service-learning. While the interviews had multiple foci, for this study we concentrated on questions that prompted alumni's comments on their career paths and perceptions of how the program informed their decisions, including: How did you get from the program to where you are now? Describe the professional positions you've held since graduation. How did you get into the work that you now do? How do you feel about this work? In what ways do you see it as similar or different from the work you were doing as part of the [service-learning] program?

\section{Procedures and Analysis}

This study was approved via institutional review at one of the three institutions, and this approval was reviewed and accepted at the other two campuses. Eligible alumni were emailed to participate in an interview about their experiences in the service-learning program and their reflections on the program post-graduation. Approximately half were conducted in person and the rest using Skype. On average, interviews lasted 84 minutes and were digitally recorded with consent. Verbatim transcriptions of each interview were used for analysis.

Data were analyzed using thematic analysis (Boyatzis, 1998). After reviewing the transcripts and the research literature, codes were created and constant comparisons were made to make meaning of the data (Boejie, 2002). Codes included: "connecting career to program," "aligning career and passion," and "professional work that makes a dif- ference." To ensure coding reliability, the authors coded independently (over 80 intercoder agreement) and then met to negotiate the coding schema (Lombard, Snyder, Duch, \& Bracken, 2002). For this study, we focused on the code "connecting career to program." After writing memos and further analyzing the data individually and jointly, we parsed the code into three themes: awareness of self, building skills, and choosing service. Below, we explicate these themes and share reflections from alumni to demonstrate connections between alumni careers and the service-learning programs.

\section{Results}

The analysis suggests that sustained servicelearning experiences informed alumni's perceptions of their career pathways. The interviewed alumni identified and articulated a number of connections between their career decisions and the service-learning programs. Analysis of the data led to three primary themes that demonstrate how the interviewed alumni connect their careers to the programs. Through exercises, activities, and experiences, these sustained service-learning programs facilitated an awareness of self that guided alumni to their current professional work, built skills that supported them in performing that work, and developed commitments that made it possible (and even desirable) to pursue a career of service, thereby informing the career pathways of the interviewed alumni.

\section{Awareness of Self}

A desired outcome of many service-learning experiences is the development of an awareness of self, particularly acquiring the confidence to engage effectively in the community (Bringle, Studer, Wilson, Clayton, \& Steinberg, 2011), an understanding of civic responsibility and agency in responding to critical issues in society (Moely, McFarland, Miron, Mercer, \& Ilustre, 2002), and a recognition of privilege (Jones \& Hill, 2001; Mitchell, $2008,2014)$. This self-knowledge is also central to college students' career development, supporting them in understanding the type of work they might want to pursue (Rayman, 1993). Speaking to her developed self-awareness, an alumna of the fouryear program explained:

I'm not a direct service person ... I'm more ... . at the organizational level . . . I realize that I don't need to be a martyr and be on the front lines if that's not going to be sustainable for me, and I knew that from the time that I was in [the service-learning program]. (Foresight 1) 
Alumni credited the service-learning programs with helping them to gain an awareness of self that has been beneficial in their career pursuits.

\section{Confidence to engage effectively.}

As students in these programs, the interviewed alumni spent time in the community actively working to respond to a critical social issue. Alumni shared that through these opportunities, they built confidence in their abilities to engage effectively in the community by learning to work with others and enacting concrete strategies aimed at ameliorating a social concern. An alumnus of the two-year program deemed that the program "certainly helped [him] to build some of the theoretical analysis" framing his current work as a community organizer (Pioneer 1). He continued: "Being in [the servicelearning program] taught me about organizing and ... that I loved organizing, I was good at it, that was really the direction I should go in." The confidence alumni reported developing through servicelearning was one way they gained self-awareness, which they perceived as supporting their career exploration and preparation.

An alumna of the four-year program, who works in early childhood education, felt that integrating one's values into professional work was stressed in the service-learning program and remained one of the biggest lessons from her experience. Even when her career path was not clear, she shared: "I think that this program really gave me the confidence and the fortitude to just sort of follow that meandering path until I landed on what was really going to work for me" (Foresight 2).

In addition, alumni reported being affirmed through service-learning in their ability to be flexible, creative, and innovative. An alumna from the four-year program asserted: "I think this program gave us the skills to be able to do that. To not just go into the world and say what exists, but what can I help create?" (Foresight 3 ).

Understanding of civic responsibility and agency.

Civic responsibility, as an ethical framework, is the sense that an individual has an obligation to act for the benefit of society at large. Service-learning often aims to instill this value and encourage students toward this commitment (Bringle et al., 2011). Beyond this commitment toward civic responsibility, self-awareness is realized in the agency one believes one has to respond to the critical social issues present in a community. An alumnus of the four-year program noted his switch from teacher to educational administrator as a reflection of his civic agency. He shared: "I looked at administration as a way that I can look at issues schoolwide ... to see how I could have a greater impact on the school at large" (Foresight 4). Similarly, the service-learning program strengthened an alumna's belief that "you really can make a direct impact" (Manor 1). She recalled that public service was not a "commonly promoted path" and felt the servicelearning program was an "eye opener" that developed her civic agency, guiding her toward work in the non-profit sector.

An alumna of the four-year program credited her service-learning capstone with cementing her career trajectory and took valuable lessons from her project creating a clothing line "with youth that were coming out of juvenile prisons" (Foresight 5). Through the project, the alumna came to understand her role "as a supporter versus a leader" to ensure that the community served felt it had ownership. Her capstone project was successful because it was a "youth-driven design, and responsive to their interests and concerns." She emphasized: "I used what I knew about manufacturing and production and design to support them in bringing their vision to the community" (Foresight 5). This experience encouraged her development of civic agency. She realized her ability to facilitate processes that fostered more justice for the youth workers. This self-awareness informed her later work organizing garment workers petitioning for fair labor practices.

The alumni perceived civic responsibility and civic agency as being developed in the servicelearning programs, which contributed to their selfawareness. These examples further demonstrate connections the alumni draw between their servicelearning experiences and current work.

\section{Recognition of privilege.}

Addressing the social locations of servicelearners and the community members with which they engage is often touted as an important practice in service-learning (Jones \& Hill, 2001; Mitchell, 2008, 2014). Studying social stratification assists students in understanding systemic injustices as well as identifying their own privilege. Through the service-learning programs, the students "began to learn about the history of movements and gender identity development, and race, and class ... you realize your placement" (Manor 2). Understanding "your placement," the alumni reflected, provided an awareness of self that informed future work. An alumnus of the four-year program who works as a political strategist acknowledged that the servicelearning program helped him realize his uppermiddle-class White privilege. He noted: 
This program showed me that the life that I had and the type of upbringing that I had is very different than the folks that I was working with [in the community] . . . That experience and that enlightenment, I think, goes a great distance in working where I am now and being able to understand the problems and the struggles that folks on the South Side, or in parts of the West End might experience ... [B]eing able to ... have the understanding and the perspective that my perspective isn't the only one, goes a great distance in the professional stuff that I have to do. (Foresight 6)

Through service-learning, he concluded, he developed the self-awareness necessary to be effective in his current work.

In the service-learning programs, the students were encouraged (and often required) to reflect on their social location. The recognition of privilege developed through the service-learning programs informed the path and purpose of the alumni's careers. An alumna of the two-year program explained: "I'm putting all my privilege to use you know, and I am so privileged to have gotten this education and understand that I need to be doing more" (Pioneer 2).

These examples illuminate the alumni's perceptions of how awareness of self was explored and developed through sustained service-learning programs. They credited the programs with informing their career decisions by aiding in the cultivation of their confidence, an understanding of their agency, and the recognition of their privilege.

\section{Building Skills}

Much service-learning research highlights changes in attitudes (e.g., Moely et al., 2002) and outcomes (e.g., Astin, Vogelgesang, Ikeda, \& Yee, 2000), but the development of practical and professional skills that support career development has also been noted to be a product of service-learning (Astin \& Sax, 1998; Hansen et al., 2007). In this research, the alumni pointed to skills built through the servicelearning programs as critical factors in their career development. These skills included working in teams, communication, and community organizing.

\section{Working in teams.}

The service-learning programs from which these alumni graduated emphasized collaboration and teamwork as important skills. In their service experiences, students worked with other volunteers, non-profit staff, and community members to implement strategies and programs aimed to ameliorate social problems. In classroom settings, the students worked together on papers and projects, cofacilitated discussions, and engaged in dialogues aimed at problem-solving and strategic planning. These experiences led the alumni to declare working in teams a skill they practiced and mastered as participants in the service-learning programs.

Speaking to the teambuilding skills he believed were developed as a student, an alumnus from the one-year program referred to an exercise often practiced in the service-learning program that focused on four Cs: "communication, coordination, cooperation, and collaboration" (Manor 3). Each $\mathrm{C}$ represented a higher rung on a ladder of group effectiveness, and he recalled this exercise being instrumental to working with peers. Now a physician, the alumnus used this exercise in his residency training, sharing it with colleagues. As they worked together, he would ask: "Are we only communicating right now, and just reading each other's notes and maybe talking on the phone? Are we coordinating ... how can we reach the level of collaboration?" (Manor 3). This alumnus practiced and built effective teamwork skills in the service-learning program that he continued to rely on to rally his colleagues in their work.

Working in teams created space to challenge each other's perspectives and practice democratic processes like decision-making by consensus. Offering an example of a class that required students to determine final grades collectively, an alumna of the four-year program reflected:

\section{We spent probably 12 hours straight in there... challenging each other's thinking ... [I]t came down to grading ... Did we want it to be an in- dividual grade or a group grade? And that was after a year of being together. (Foresight 3 )}

The intense conversation represented more than just a grade - it was about balancing individual desires with the good of the group. They were practicing skills essential to teamwork that this alumna applied in her job as a social worker.

The programs prepared students to work effectively in diverse teams with people who had different, and often conflicting, perspectives. An alumna from the two-year program shared that the diversity committee at her workplace was made up of all White people whom she felt were "scared to talk about conflicts, scared to talk about identity work" (Pioneer 3). While she also identified as White, she joined the committee hoping to shift the culture. Throughout the year, the group began building relationships and trust and reached out to the rest of the staff. Reflecting on how the program assisted her in this process, she said: 
These skills you get, being in a classroom for two years working with the same group of people and really processing group dynamics, [are] invaluable when you go into an organization ... you can bring really critical skills to group work. (Pioneer 3)

Working together across differences was a skill promoted and practiced that alumni perceived as beneficial and continued to utilize in their careers.

\section{Communication.}

Proficiency in written and oral communication was touted by the alumni as a skill practiced and developed in their service-learning programs. Through service experiences, the students worked to build and deepen relationships with people at their service sites, often moving between conversations with directors of non-profits, children and young people they mentored or tutored, low-income workers, classroom teachers, and people who had experienced homelessness. Engaging in meaningful dialogue with individuals with diverse identities and experiences left the alumni confident they could "have conversations with just about anyone" (Pioneer 4). In the classrooms, the service-learning students gave public presentations, facilitated discussions, and engaged in debates that provided opportunities to practice both speaking and "deep listening" (Foresight 7).

A two-year program alumnus, who is a physician, explained that the service-learning program taught him to interact with patients in a "conversive" rather than "didactic" way (Pioneer 5). He explained how he talks with patients about their diabetes: "I don't try to lecture to them. I say, 'What changes can we make in your life that are practical to you? How do we tailor this to you?'" (Pioneer 5).

Another alumnus of the same program valued the facilitation skills he gained to "create spaces that enable people to feel empowered and come to a place of collective action" in his community organizing work (Pioneer 1). He shared: "I think a lot of my facilitation skills are informed by my experiences in service-learning." This alumnus considers his facilitation empowering for others, noting: "I feel really fortunate to have gained [these skills] because I know that they're not necessarily easy skills to have."

Through personal reflections, writing assignments, and creative exercises, the alumni learned to articulate their perspectives, share their identities, tell their stories, and frame compelling arguments. From working as a communications director for a large city mayor (Foresight 8 ) to "doing research that can make a political impact" (Manor 4), alumni credited the service-learning programs with helping them build the communication skills important to their professional work.

\section{Community organizing.}

The service-learning programs emphasized preparing students to identify and implement creative and sustainable solutions to concerns and issues in the local community. With this goal in mind, the community experiences and classroom assignments often engaged the students in work informed by the principles and practices of community organizing. The alumni, both through career choice and approaches to addressing issues in their work, indicated the training and experience they received around community organizing was deeply influential.

An alumna from the two-year program explained: "this path that I'm on of organizing . . . all starts from learning organizing in [the servicelearning program]" (Pioneer 6). Similarly, an alumna from the one-year program (Manor 5) spoke of the importance of the community organizing skills she built during the program. After college, she used those skills to engage in community organizing around single-room occupancy tenants' rights and then through a harm reduction program for drug users.

An alumnus of the two-year program described his current work, organizing low-income community members around affordable housing, as "trying to do something to empower or improve the lives of people who are struggling in a lot of ways to secure ... a healthy, comfortable lifestyle" (Pioneer 4). The alumni perceived that the focus on community organizing in the service-learning programs supported them in developing skills appropriate to professional work aimed toward making change.

These examples illustrate the ways that multiterm service-learning programs support students in building skills to work in teams, communicate effectively, and organize for change in their communities. The alumni viewed their careers as reflective of the skills they developed through servicelearning.

\section{Choosing Service}

Service-learning has been applauded for its plausible contributions to career preparation (Duffy \& Sedlacek, 2007; Warchal \& Ruiz, 2004), but also, perhaps more importantly, for its ability to motivate students toward careers focused on improving circumstances and conditions for others (Jones \& Abes, 2004; Vogelgesang \& Astin, 2000). Through 
their service-learning programs, the alumni felt able to connect to job opportunities focused on the public good that allowed them to meaningfully serve others through professional work.

\section{Selecting careers with civic commitments.}

The interviewed alumni discussed devoting themselves to public service careers post-college. A one-year program alumnus felt that the program "really reinforced an already existing desire to do something that I found to be meaningful and interesting, [to work for] social justice" (Manor 6). An alumna from the four-year program spoke of a "filter" the program helped her develop in thinking about her professional work. She asked: "how does this reflect ... my values and how does what I do really reflect who I am as a person?" (Foresight 9). Similarly, a two-year program alumna described how the service-learning program influenced "everything I did" with regard to her career. She explained:

\begin{abstract}
At one point I had the opportunity to work in marketing for a property management company and I started working there but then . . . I could stay there or I could start a job where I was going to be teaching adults workplace math. And the marketing job was making triple what the workplace math job was going to be ... I was in grad school, you know it would really help but at the end it was living with myself and knowing that my actions mattered ... that was where it clicked that it's going to be more than just putting food on a plate. (Pioneer 8)
\end{abstract}

The alumni credited the programs with inspiring their commitments and choices about where to work and what type of job to take. An alumnus of the two-year program shared: "I definitely think my venture into education was influenced by the program" (Pioneer 9).

Perceiving the environment created by the service-learning programs as one that made it appropriate, and even desirable, to commit to professional work that mattered, alumni felt capable of choosing careers focused on creating meaningful change above financial gain.

\section{Job placement.}

Service-learning programs often expose students to a variety of career options (Franta, 1994; Savickas, 1999). Because service-learning facilitates engagement at schools, after-school programs, advocacy groups, arts organizations, government of- fices, and myriad non-profits, students are exposed to a number of career options that allow them to align their personal commitments and professional work. Through the community leaders and professionals at their service placements, and the guest speakers invited to different classes, the alumni believed they were able to grow their networks and move beyond their college communities.

Representative of the career networks alumni believed were developed during the service-learning programs, some alumni shared that their first fulltime professional work after college came directly from relationships created through their servicelearning placements. An alumna of the two-year program explained: "[T]he job I have right now ... came directly out of my volunteer service with [the program]" (Pioneer 3). An alumna from the fouryear program accepted a job from the domesticviolence agency where she volunteered her senior year for her capstone class. She commented that it was "really great to have a job right out of college. I didn't even have to look for one" (Foresight 7). Another alumna of that program described how her service placement led to employment: "[W] hen I started here freshman year, I got a volunteer position at the local community center, and I stayed there through my four years and worked into a job and then got a full-time job when I graduated" (Foresight 2). Alumni developed relationships through their community service, but more importantly, they developed an understanding of the service agency and its work that allowed them to transition seamlessly into paid roles at those same organizations.

While not every alumni interviewed for this study was directly connected to a professional position because of their community work as a servicelearning student, the networks developed introduced many alumni to different job opportunities that allowed them to utilize the skills and awareness developed through the program in service-oriented professional positions.

\section{Discovering civic possibilities.}

Most respondents in this study chose jobs in the service sector, seizing opportunities to align their professional work and civic commitments. Other alumni, however, pursued careers not solely associated with public service - jobs in business, medicine, law, or higher education. An occupation outside of the traditional service sector, however, does not mean people cannot or do not position themselves to do civic work in their careers (Colby, Beaumont, Erlich, \& Corngold, 2007). Several alumni in careers outside the public service sector 
revealed that they looked for opportunities to engage civically, even if their primary work responsibilities were not typically structured as such.

An alumna of the one-year program, a full-time graduate student studying political theory, appreciated that the program encouraged her toward engaged scholarship. The program affirmed that research could be inspired by "personal experience and outrage at injustice and [that] wanting to do something about it didn't invalidate it" (Manor 4). It left her confident that she "could still do good research while still maintaining [her] political perspective" in her doctoral work. Similarly, a law professor who runs a family law clinic on her campus emphasized the civic dimensions of her work: "I get to represent real people who can't afford legal services and I teach students how to do that" (Manor 7).

Other alumni served others by engaging in opportunities above the requirements of their jobs. Expanding his work beyond the hospital, a physician from the two-year program took two weeks of vacation to lead medical mission trips to the Dominican Republic. Working with a team of people to "teach [the] community about better health and deliver primary care," he described the work as the "most rewarding work I've done to date in my life" and planned to extend the opportunity to medical students (Pioneer 5).

An alumna from the four-year program who owns a drop-in play center for children and their caretakers aimed "to still do good with the business that I have" by doing outreach to "foster care agencies to see if foster care kids would want to come in [for free] . . . I feel like sometimes it's small gestures, but it's ways that I can still feel connected" (Foresight 2). These alumni provided examples of elevating the civic possibilities of their work.

\section{Discussion and Implications}

Most prior research exploring career development and service-learning have considered either a single course experience (Jones \& Abes, 2004; Youniss \& Yates, 1997) or multiple unconnected experiences, such as a service-learning course and 40 hours of service (Fenzel \& Peyrot, 2005; Warchal \& Ruiz, 2004). This study is unique in its ability to look at the perceived influence of continuous and integrated service-learning experiences and to consider the implications of such programs on the career decisions of alumni. This research adds to the literature contending rich connections between service-learning experiences and career decisionmaking.

The alumni in this study credited their service- learning programs with helping them deepen their awareness of their interests, values, and skills, which career development theory emphasizes is key to discerning a successful and satisfactory career path (Pipkins et al., 2014). According to SCCT, this time and space to recursively develop skills, clarify values and interests, and make choices about career prospects that are necessary for self-efficacy and career choice are central to satisfactory career development.

In addition, through service-learning, the students learned about various career opportunities and rehearsed roles to further define their interests and refine their skills. These "interventions," such as the direct experience of service, reflection, and stories of the self, fed rich information "into the system," possibly influencing students' career decision-making (Krieshok, 1998, p. 219). Each program included a capstone requirement wherein the students participated in community work and imagined their career steps post-graduation. In this way, the programs provided occupational engagement "that contribute[d] to the career decisionmaker's fund of information and experience of the larger world" and supported the alumni in making more informed career decisions (Krieshok et al., 2009, p. 284).

The alumni perceived that the programs created spaces and experiences that allowed them to develop civic commitments that persisted beyond their undergraduate years. Service-learning students became alumni who sought opportunities to work for the public good. While many alumni from these programs chose careers that directly connected them with their sense of civic responsibility, others found ways to exercise their civic values through their approaches to their professional work, making choices about focus, location, and clientele that matched their civic commitments.

This research demonstrates how service-learning experiences inform the career exploration, preparation, and motivations of alumni. The opportunities to explore interests, develop commitments, build networks, and engage in meaningful work were important in steering these alumni's career decisions toward the public good. This research suggests that practitioners should be mindful that service-learning contributes to the experiences and information students accumulate that support career decisions. Service-learning has long focused on democratic engagement - emphasizing political participation and community service - with little thought to how the careers alumni pursue can also reflect civic potential. Career-development specialists and service-learning practitioners can work together to direct community engagement 
experiences with intention that supports students in considering the civic possibilities of their future professional work.

\section{Limitations}

As this research is correlational, we acknowledge that these alumni - who as students elected to participate in a sustained service-learning program - may be predisposed to service-oriented careers by virtue of their interests and that the programs merely deepened already established commitments to public service work. In addition, this study relies on the alumni's retrospective sensemaking. The alumni drew strong connections between undergraduate experiences and their careers - in some cases, 15 years later. We assume, because of their detailed and passionate retellings, that as the alumni shared their experiences of the service-learning programs, they were detailing a "conscious processing" of their career decisions (Krieshok, 1998, p. 221). However, Krieshok warns that while there may be rich connections between these service-learning experiences and the alumni's career paths, they could also be the product of "a set of stories decision makers tell themselves and others" to make up for the limited access to the "actual processing" that may occur in career decision-making (p. 221). Both service-learning and career development would be well served by longitudinal research that explores these connections.

\section{Conclusion}

Career development has long emphasized the importance of students' interests, values, skills, and motivations as crucial determinants of their career decisions, yet there is a dearth of literature about college alumni and how they make sense of their career choices. This study has helped to explicate the enduring influences of community engagement experiences, which is important given the expansion of civic learning opportunities and the recent considerations of service-learning's influence on workforce development. Note that almost half of U.S. states identify service-learning as a way to prepare students for the workforce (Education Commission of the States, 2014). This research suggests that service-learning can, indeed, be an effective method for workforce development, especially toward careers that also aim to work for the public good.

The majority of the alumni represented in this study chose careers in public service, but even those who did not discussed consciously looking for ways they could enhance the civic dimension of their professional position by working with others to address challenges in their communities. Finding public purpose within all types of employment and using one's position to work in collaboration with other citizens for the public good is what Boyte and Fretz (2010) call "civic professionalism" (p. 81). Similarly, Hatcher (2008) has defined the "civicminded professional" as someone with "an ethical disposition to regard oneself as a social trustee of knowledge with a responsibility to work with others, both professionals and citizens, to achieve the common good" (p. 20). These scholars argue that civic professionalism is vital to maintaining a healthy democracy. The present study suggests that the development of civic professionals may be an outcome of sustained service-learning experiences as alumni credit these experiences with informing their career pathways. As students, they were able to develop an awareness of self and build skills that they perceived as instructive and integral to fulfilling civic responsibilities through their professional work.

\section{References}

Astin, A. W., \& Sax, L. J. (1998). How undergraduates are affected by service participation. Journal of College Student Development, 39(3), 251-263.

Astin, A. W., Vogelgesang, L. J., Ikeda, E. K., \& Yee, J. A. (2000). How service learning affects students. Los Angeles: Higher Education Research Institute, University of California.

Bandura, A. (1986). Social foundations of thought and action. Englewood Cliffs, NJ: Prentice Hall.

Billig, S. H. (2000). Research on K-12 school-based service-learning: The evidence builds. Phi Delta Kappan, 81(9), 658-664.

Boejie, H. (2002). A purposeful approach to the constant comparative method in the analysis of qualitative interviews. Quality and Quantity, 36, 391-409.

Bonitz, V. S., Larson, L. M., \& Armstrong, P. I. (2010). Interests, self-efficacy, and choice goals: An experimental manipulation. Journal of Vocational Behavior, 76(2), 223-233.

Boyatzis, R. E. (1998). Transforming qualitative information: Thematic analysis and code development. Thousand Oaks, CA: SAGE.

Boyte, H. C., \& Fretz, E. (2010). Civic professionalism. Journal of Higher Education Outreach and Engagement, 14(2), 67-90.

Bringle, R. G., \& Hatcher, J. A. (1996). Implementing service learning in higher education. The Journal of Higher Education, 67, 221-239.

Bringle, R. G., Studer, M., Wilson, J., Clayton, P. H., \& Steinberg, K. S. (2011). Designing programs with a purpose: To promote civic engagement for life. Journal of Academic Ethics, 9(2), 149-164. 
Celio, C. I., Durlak, J., \& Dymnicki, A. (2011). A metaanalysis of the impact of service-learning on students. Journal of Experiential Education, 34(2), 164-181.

Colby, A., Beaumont, E., Erlich, T., \& Corngold, J. (2007). Educating for democracy: Preparing undergraduates for responsible political engagement. San Francisco, CA: Jossey-Bass.

Denson, N., Vogelgesang, L. J., \& Saenz, V. (2005, April). Can service learning and a college climate of service lead to increased political engagement after college? Paper presented at the Annual Meeting of the American Educational Research Association, Montréal, Québec, Canada.

Duffy, R. D., \& Sedlacek, W. E. (2007). What is most important to students' long-term career choices: Analyzing 10-year trends and group differences. Journal of Career Development, 34, 149-163.

Education Commission of the States. (2014). Servicelearning/community service as a strategy for fostering student outcomes. Retrieved from http://ecs.force. $\mathrm{com} / \mathrm{mbdata} / \mathrm{mbquest3RTE}$ ?Rep=SL1303

Fenzel, M., \& Peyrot, M. (2005). Comparing college community participation and future service behaviors and attitudes. Michigan Journal of Community Service-Learning, 12(1), 23-31.

Franta, P. (1994). Service-learning: A new priority for career centers. Journal of Career Development, 21, 131-134.

Hackett, G. (1995).). Self-efficacy in career choice and development. In A. Bandura (Ed.), Self-efficacy in changing societies (pp. 232-258). Cambridge, UK: Cambridge University Press.

Hansen, A. M. W., Muñoz, J., Crist, P. A., Gupta, J., Ideishi, R. I., Primeau, L. A., \& Tupé, D. (2007). Service learning: Meaningful, community-centered professional skill development for occupational therapy students. Occupational Therapy in Health Care, 21(1-2), 25-49. doi:10.1300/J003v21n01_03

Hatcher, J. A. (2008). The public role of professionals: Developing and evaluating the Civic-Minded Professional scale (Doctoral dissertation). Available from ProQuest Dissertation and Theses. (AAT 3331248)

Jacoby, B. (2009). Civic engagement in higher education: Concepts and practices. San Francisco, CA: Jossey-Bass.

Jones, S. R., \& Abes, E. S. (2004). Enduring influences of service-learning on college students' identity development. Journal of College Student Development, 45(2), 149-166.

Jones, S. R., \& Hill, K. (2001). Crossing high street: Understanding diversity through community servicelearning. Journal of College Student Development, 42(3), 204-216.

Kahne, J. E., \& Sporte, S. E. (2008). Developing citizens: The impact of civic learning opportunities on students' commitment to civic participation. American Educational Research Journal, 45, 738-736.

Kolenko, T. A., Porter, G., Wheatley, W., \& Colby, M. (1996). Critique of service learning projects in man- agement education: Pedagogical foundations, barriers, and guidelines. Journal of Business Ethics, 15, 133142.

Krieshok, T. S. (1998). An anti-introspectivist view of career decision making. Career Development Quarterly, 46(3), 210-229.

Krieshok, T. S., Black, M. D., \& McKay, R. A. (2009). Career decision making: The limits of rationality and the abundance of non-conscious processes. Journal of Vocational Behavior, 75(3), 275-290.

Lent, R. W., Brown, S. D., \& Hackett, G. (1994). Toward a unifying social cognitive theory of career and academic interest, choice, and performance. Journal of Vocational Behavior, 45(1), 79-122.

Lent, R. W., Brown, S. D., \& Hackett, G. (2000). Contextual supports and barriers to career choice: A social cognitive analysis. Journal of Counseling Psychology, 47(1), 36-49.

Lombard, M., Snyder-Duch, J., \& Bracken, C. C. (2002). Content analysis in mass communication: Assessment and reporting of intercoder reliability. Human Communication Research, 28(4), 587-604.

Meaney, K. S., Housman, J., Cavazos, A., \& Wilcox, M. L. (2012). Examining service-learning in a graduate physical education teacher education course. Journal of the Scholarship of Teaching and Learning, 12(3), 108-124.

Mitchell, T. D. (2008). Traditional vs. critical servicelearning: Engaging the literature to differentiate two models. Michigan Journal of Community Service Learning, 14(2), 50-65.

Mitchell, T. D. (2014). How service-learning enacts social justice sensemaking. Journal of Critical Thought and Praxis, 2(2), Article 6. Retrieved from http://lib. dr.iastate.edu/jctp/vol2/iss $2 / 6$

Moely, B. E., \& Ilustre, V. (2014). The impact of servicelearning course characteristics on university students' learning outcomes. Michigan Journal of Community Service Learning, 21(1), 5-16.

Moely, B. E., McFarland, M., Miron, D., Mercer, S., \& Ilustre, V. (2002). Changes in college students' attitudes and intentions for civic involvement as a function of service-learning experiences. Michigan Journal of Community Service Learning, 9(2), 18-26.

Odera, E., Lamm, A. J., Odera, L. C., Duryea, M., \& Davis, J. (2015). Understanding how research experiences foster undergraduate research skill development and influence STEM career choice. NACTA Journal, 59(3), 180-188.

Pipkins, K. C., Rooney, G. S., \& Jaunarajs, I. (2014). Back to the basics: Career counseling. New Directions for Student Services, 148, 35-48.

Rayman, J. R. (1993). Contemporary career services: Theory defines practice. New Directions for Student Services, 62, 3-22.

Savickas, M. L. (1999). The transition from school to work: A developmental perspective. The Career Development Quarterly, 47, 326-336.

Savickas, M. L., Nota, L., Rossier, J., Dauwalder, J. P., 
Duarte, M. E., Guichard, J, et al. (2009). Life designing: A paradigm for career construction in the 21 st century. Journal of Vocational Behavior, 75, 239-250.

Schnoes, A. M., Caliendo, A., Morand, J., Dillinger, T., Naffziger-Hirsch, M., Moses, B, et al. (2018). Internship experiences contribute to confident career decision making for doctoral students in the life sciences. CBE Life Sciences Education, 17(1), Article 16.

Simons, L., \& Cleary, B. (2006). The influence of service learning on students' personal and social development. College Teaching, 54(4), 307-319. doi:10.3200/ CTCH.54.4.307-319

Vogelgesang, L. J., \& Astin, A. W. (2000). Comparing the effects of community service and service-learning. Michigan Journal of Community Service Learning, 7(1), 25-34.

Warchal, J., \& Ruiz, A. (2004). The long-term effects of undergraduate service-learning programs on postgraduate employment choices, community engagement, and civic leadership. In M. Welch \& S. H. Billig (Eds.), New perspectives in service-learning: Research to advance the field (pp. 87-106). Greenwich, CT: Information Age.

Youniss, J., \& Yates, M. (1997). Community service and social responsibility in youth. Chicago, IL: The University of Chicago Press.

\section{Authors}

TANIA D. MITCHELL (tmitchel@umn.edu) is an associate professor of higher education at the University of Minnesota's College of Education and Human Development. Her teaching interests include leadership, service and social change, diversity in higher education, and college student development. Much of her research focuses on community engagement strategies as opportunities for critical praxis and to explore civic identity, social justice, student learning and development, race and racism, and community practice.

COLLEEN ROST-BANIK (rostb007@umn.edu) is a doctoral candidate at the University of Minnesota and is in the process of completing her dissertation. Currently living, conducting research, and teaching in Hawai' $i$, she is interested in the social and cultural contexts in which undergraduates learn about and enact racial and economic (in)justice. 